ojs.uv.es/index.php/qdfed

Rebut: I0.05.2021. Acceptat: I4.07.2021

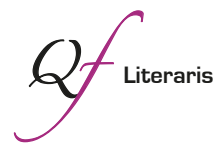

Per a citar aquest article: Rodríguez Jiménez, José Luis. 202I. "Perpetradores de violencia. El arquetipo de funcionario de la policía política y propagandista de la teoría de la conspiración antiespañola:

Mauricio Carlavilla y Eduardo Comín Colomer". Quaderns de Filologia: Estudis Literaris XXVI: I03-I27.

doi: $10.7203 /$ qdfed.26.22102

\title{
Perpetradores de violencia. El arquetipo de funcionario de la policía política y propagandista de la teoría de la conspiración antiespañola: Mauricio Carlavilla y Eduardo Comín Colomer
}

Perpetrators of violence. The archetype of a political police officer and propagandist for the anti-Spanish conspiracy theory: Mauricio Carlavilla and Eduardo Comín Colomer

\author{
JosÉ LUIS RODRÍGUEZ JIMÉNEZ \\ Universidad Rey Juan Carlos \\ jose.rodriguez@urjc.es
}

Resumen: No existe un listado de personas y organismos perpetradores de la violencia franquista, ni oficial ni oficioso. No obstante, nuestro objeto de estudio es la doble figura de funcionario de la policía política y difusor de la teoría de la conspiración judeo-masónica-comunista como perpetrador de violencia durante el periodo I936-I975. Pues, en ausencia de figuras criminales individuales y colectivas para los crímenes cometidos durante ese periodo, nos preguntamos: ¿es esa doble figura (y por supuesto la figura individual de policía político de la Dictadura) un arquetipo de perpetración de violencia por el franquismo? También nos preguntamos por la utilidad de esa doble labor desempeñada por algunos cargos de la policía franquista. Para avanzar en las respuestas, en este artículo estudiamos las figuras de Mauricio Carlavilla y Eduardo Comín Colomer.

Palabras clave: policía política; represión franquista; teorías conspirativas; Carlavilla; Comín Colomer.

Abstract: There is no official or unofficial list of people and organizations that perpetrated
Franco's violence. However, our object of study is the double figure of official of the political po-
lice and diffuser of the Judeo-Masonic-Communist conspiracy theory as perpetrator of violence
during the period from I 936 to I975. Since, in the absence of individual and collective criminal
figures for the crimes committed during that period, we ask ourselves: is this double figure
(and of course the individual figure of the political police of the Dictatorship) an archetype of
perpetration of violence by Francoism? We also wonder about the usefulness of this double
task carried out by some positions of the Francoist police. To advance the answers, in this arti-
cle we study the figures of Mauricio Carlavilla and Eduardo Comín Colomer. Keywords: Political police; Franco's repression; conspiracy theories; Carlavilla; Comín Colomer. 


\section{Metodología}

El objeto de estudio es la doble figura de miembro de la policía política y propagandista de la teoría de la conspiración judeo-masónica-comunista, en su versión española como perpetrador de violencia durante la Segunda República, la Guerra Civil y el franquismo. Siendo así, planteamos la investigación a partir de varias preguntas.

No existe un listado oficial de personas y organismos perpetradores de la violencia ejercida por el bando sublevado durante la Guerra Civil y el régimen de Franco, ni siquiera oficioso. Contamos con un caso emblemático de un tribunal internacional que ha juzgado un régimen político tras su derrota. Se trata del Tribunal de Núremberg, que, antes de juzgar los crímenes cometidos por el Tercer Reich, estableció nuevas figuras delictivas, así como las organizaciones de este régimen que serían consideradas criminales, determinando, en consecuencia, que sus miembros tenían una responsabilidad criminal que sería establecida por el tribunal que les juzgara: el Cuerpo de Jefes del Partido Nazi; las SS, Escuadras de Seguridad del Partido; también, en concreto, la Ausland-SD, División de Inteligencia Exterior de las SS, que era la Oficina VI del departamento de inteligencia de la Oficina Central de Seguridad del Reich (RSHA), en el Ministerio del Interior del Reich; y la Gestapo, Policía Secreta del Estado, otra de las secciones de la RSHA. Más habitual ha sido que la justicia internacional establezca tribunales para juzgar a personas concretas, consideradas responsables de los delitos de crímenes de guerra y de genocidio, y que justicias nacionales procesaran a personas consideradas responsables de crímenes cometidos durante un régimen dictatorial desaparecido. En el caso de Argentina, han sido procesados militares, policías y civiles acusados de violaciones a los derechos humanos durante la dictadura militar del periodo I976-I983, es decir, personas concretas y no organizaciones, y no todos los miembros de las juntas militares fueron condenados.

Ni el modelo del Tribunal de Núremberg ni el argentino han sido aplicados al caso del franquismo. Ningún tribunal ha pretendido establecer una lista completa y coherente de posibles responsables de crímenes contra la humanidad o de genocidio, y ninguno ha tratado de establecer figuras criminales colectivas, sin que deban obviarse los autos del juez Baltasar Garzón y la querella argentina instruida por la jueza María Romilda Servini. Siendo así, cabe preguntarse: en ausencia de figura criminal colectiva para los crímenes cometidos durante la Guerra Civil y el franquismo, ¿es la doble figura de miembro de la policía política y propagandista de la teoría de la conspiración 
judeo-masónica-comunista un arquetipo de perpetración de violencia por el franquismo?

Consideramos que la propaganda política y la ideología pueden ser expresiones de violencia. También que las dictaduras establecen enemigos interiores, en ocasiones también exteriores, y que su aparato de propaganda incide sobre los enemigos reales y supuestos, para crear la impresión de que esos enemigos son muy poderosos, y que por ese motivo hay que dedicar muchos esfuerzos a combatirlos, y que no son solo una encarnación de un modelo político y económico distinto, sino también de un poder maléfico, oscuro, subterráneo, que, si no se le combate, acaba por infiltrarse en una sociedad, para destruirla. Como muestran los estudios de los maestros Cohn y Poliakov, es con este fin con el que se crean teorías conspirativas, en las que siempre hay un enemigo visible. Pero puede haberlo también invisible, al menos en el país afectado, por tener su centro de operaciones en un lugar alejado, incluso por ser sobrenatural, una creación del demonio, o ser el mismo demonio. Pues bien, en el caso que nos ocupa, ¿cuál es la importancia de las teorías de la conspiración, en concreto de la conspiración judeo-masónica-comunista contra España, en la argumentación y justificación de la violencia contra los enemigos del franquismo?

En cuanto a la teoría de la conspiración antiespañola que los policías Carlavilla y Comín retoman y alimentan, ¿tiene las mismas intenciones que en los autores que les proceden en este cometido?, ¿incorpora nuevos propósitos al trabajar en coyunturas interior e internacional distintas?, y, entonces, ¿crea nuevas imágenes, nuevos enemigos, para hacer una representación más completa de la anti-España, de los enemigos del franquismo? En resumen, ¿qué tipología de representaciones del antifranquismo generan? También nos preguntamos: ¿Es una figura esquiva la del policía-ideólogo como perpetrador de violencia?, ¿existe dificultad para identificar figuras concretas? ¿Cuál fue la utilidad de estos policías-ideólogos y qué efectos tuvo su trabajo para la prolongación de la dictadura? A partir de su labor policial y de su labor en tareas de propaganda mediante la redacción de libros, ¿existe dificultad para nombrar la violencia?, ¿para determinar de qué forma perpetran violencia?

También planteamos dos hipótesis. La primera: los policías políticos-propagandistas de la teoría de la conspiración constituyen una figura concreta y doble, del perpetrador de violencia política. Es decir, son agentes de violencia política de dos modos: como policías y como propagandistas y, en ambos casos, con consecuencias materiales para los señalados como enemigos. La segunda: el conocimiento de su labor es esencial para conocer mejor el sistema de represión franquista. 
En cuanto a las fuentes, hemos recurrido a la bibliografía académica sobre teorías de la conspiración y en concreto sobre la judeo-masónica-comunista en España. La bibliografía académica sobre este tema es amplia. No puede decirse lo mismo respecto a la policía política franquista y española en general. Así se expone en una tesis doctoral reciente, que refleja la abundancia de estudios sobre la represión y la escasez de materiales sobre el conjunto de la acción policial (Alcántara Pérez, 2020: 23); y poco hay, ciertamente, sobre la policía política franquista en las historias de la policía de Caamaño, De Antón, López Garrido y Turrado; algo más en los trabajos centrados en la época franquista, a menudo para tratar un territorio o una cronología, aunque apenas entran en el tema que nos ocupa. Obviamente, hemos analizado la obra de los policías Mauricio Carlavilla y Eduardo Comín Colomer. Asimismo, hemos consultado la documentación disponible sobre ambos personajes en el Archivo General de la Guerra Civil Española y el Archivo General de la Policía en el Ministerio del Interior.

\section{Aparatos represivos y doctrinas antisubversivas}

Los aparatos represivos (la violencia del Estado y paraestatal) desempeñan un papel fundamental en los regímenes dictatoriales y llegan a alcanzar una notable complejidad. Fuerzas militares y de seguridad, de la que forman parte la policía política y los servicios de inteligencia, trabajan para perpetuar regímenes dictatoriales. La doctrina antisubversiva, del signo que sea, justifica la actuación de la policía y del ejército contra los denominados "enemigos" y "amenazas", interiores y exteriores, al sistema político, económico y cultural impuesto. Además, exagera las capacidades de los enemigos reales, para, aumentando su peligrosidad, justificar la represión, y sus excesos, y que la actuación represiva sea bien considerada y premiada por los dirigentes. También inventa enemigos, a los que llega a calificar de agentes de Satán o de cualquier otro mito demoniaco (Cohn, I980: 37 y ss.; Cohn, I983: 40-4I; Ferrer, I982: 3I y ss.), para, asimismo, exagerar el peligro, y que, en una situación crítica para ellos, sintiendo en riesgo sus intereses, y tal vez también sus personas, los afines, aunque no entusiastas del régimen, cierren filas en torno al Gobierno y al dictador. También, modela la figura del enemigo, para que la propaganda resulte más eficaz, a partir de experiencias previas que demuestran que ese tipo de propaganda es rentable. Esto supone crear o recrear una figura del enemigo adecuada a sus objetivos, que no está diseñada para convencer a la 
totalidad de las personas, dentro y fuera de un Estado, sino para mantener movilizados a los ya convencidos, a las bases sociales del sistema, tanto a las iniciales como a las generadas durante la dictadura en el caso de regímenes de larga duración como fue el franquismo, para que ambas cierren filas en defensa de los ideales enunciados en el momento fundacional. Asimismo, debe resultar útil -junto a otros factores, principalmente económicos- para convencer a una parte de los moderados del régimen dictatorial y para sembrar dudas entre otros, de no colaborar con la oposición, para que ni siquiera se animen a ser voz disidente en algún tema concreto y, menos aún, a criticar los "excesos" de la represión. En el caso del franquismo, los enemigos aparecen contenidos en la teoría de la conspiración antiespañola.

\section{La teoría de la conspiración antiespañola}

\subsection{La conspiración judeo-masónica-comunista}

Con la expresión "teoría de la conspiración" o "visiones policíacas de la Historia" hacemos referencia a un mundo de supuestas intrigas, conjuras y conspiraciones que ha proporcionado una alta rentabilidad a experimentados agitadores y conspiradores en todas las épocas. Una amplia gama de grupos religiosos y políticos han elaborado a lo largo de la historia complejas teorías conspirativas con diversos fines. Primero, para explicar sus miedos. También para fundamentar su condena de cambios acontecidos en el terreno de las estructuras sociales y de las mentalidades que perjudicaban a sus intereses. Finalmente, para desviar la atención de la opinión pública respecto a los fines perseguidos, ya sean de tipo cultural, económico, político o geoestratégico.

En la Antigüedad y en la Edad Media, los sujetos a los que se consideraba causantes de catástrofes naturales, epidemias y guerras solían ser miembros de una minoría religiosa, extranjeros, forasteros, prostitutas o personas acusadas de brujería. Nos encontramos de momento ante unas visiones conspirativas escasamente codificadas y operativas en un espacio geográfico reducido. Desde finales del siglo xviıI, y hasta el presente, entran en escena visiones conspirativas de alcance universal. Asimismo, aparecen nuevos temas, los cuales tienen que ver con las transformaciones experimentadas por

\footnotetext{
I Poliakov utiliza esta expresión en la obra citada, y antes en su historia del antisemitismo; la toma de autores anglosajones y dice que fue cuñada en I953 por Manès Sperber (I982: 9 y I88).
} 
la sociedad y la competencia entre Estados en el ámbito de las relaciones internacionales. La primera teoría de la conspiración de alcance universal sitúa a la masonería en el centro de una conjura dirigida contra el cristianismo y el orden social propio del feudalismo. A continuación, desde comienzos del siglo XIX, esta visión conspirativa de la historia incorpora un protagonista que ya había sido utilizado siglos atrás por los creadores de teorías conspirativas: el antisemitismo.

Durante la segunda mitad del xix, las organizaciones de la derecha autoritaria y ultranacionalista propagaron la idea de una conjura judía. En el discurso antisemita aparecían entremezclados la religión tradicional, la demagogia anticapitalista y el rechazo a la modernidad, a los cambios sociales y culturales derivados de la revolución industrial y científica. Los contrarrevolucionarios afirmaban que las transformaciones que trajeron consigo las revoluciones burguesas y el progreso de las ideas socialistas no tenían su explicación en el deseo de muchas personas de acabar con las injusticias del viejo modelo, sino en un complot, y describían el liberalismo y el movimiento obrero como un producto "judío" y, por lo tanto, se decía anticristiano y antinacional (antifrancés, antialemán, antiespañol...): los judíos, o los judíos y los masones, o los masones dirigidos por los judíos, aparecen así como responsables de una serie de males reales (crisis económicas, etc.) o inventados, léase los peligros de la modernidad, el cine, el feminismo, el metro, etc., y financiadores de todo tipo de organizaciones revolucionarias, siempre con el propósito de debilitar los Estados, destruir el orden y la moral tradicional y, en definitiva, hacerse con el control del mundo.

En las primeras décadas del siglo xx entra en escena un nuevo componente de esa "conspiración" a escala universal. Se trata del comunismo. La difusión de la obra Los Protocolos de los Sabios de Sión desempeñó un papel principal en esta cuestión. Esta obra comenzó a ganar audiencia una vez iniciada la revolución y la guerra civil en Rusia. No obstante, la idea del complot judeocomunista recibe su principal impulso a partir de otra serie de circunstancias: las tentativas revolucionarias que se dieron en los años finales e inmediatamente posteriores a la Gran Guerra y la depresión económica mundial iniciada en I929. Además, muchos ciudadanos necesitaban una explicación de los cambios en los que estaban inmersos como miembros de una colectividad, entre estos la segunda revolución industrial, la revolución tecnológica y la irrupción de las masas en la vida política, y de la cambiante situación en el panorama político nacional e internacional. Y muchos creyeron encontrar la respuesta en la citada conspiración dirigida por el judaísmo, ese "Israel" que actuaba en 
las sociedades occidentales mediante sus brazos ejecutores, la masonería y el comunismo.

\subsection{La aplicación a España de la teoría de la conspiración}

No solo los tradicionalistas y la derecha católica utilizaron el recurso de la conspiración judía, también algunas organizaciones de izquierda, la derecha radical, el nacional-socialismo y la mayor parte de las organizaciones fascistas.

La versión española de la teoría de la conspiración tiene poco de original, lo principal es el componente separatista de algunos territorios respecto al Estado. A lo largo del siglo xix, el tradicionalismo católico copió el trabajo de sus homólogos franceses, que reaccionaban contra la Ilustración, la Revolución y el régimen de Napoleón Bonaparte, para propagar la idea de que todo acontecimiento adverso a los intereses de la monarquía, de la Iglesia católica y del orden social amparado por esta era el resultado de una conspiración secreta urdida por las logias masónicas y el judaísmo. Estaba naciendo la idea de las dos Españas, o, más bien, de la España integrada por quienes deseaban conservar sus esencias y protagonizar su resurgimiento, y de la anti-España. La segunda, corrupta, inmoral y extranjerizante, se agruparía en torno al liberalismo en todas sus formas, que sería el enemigo interior, manejado por fuerzas secretas, peligrosísimas y de alcance internacional, para así desprestigiar los cambios y tener argumentos con los que defender los intereses económicos y sociales propios. Tengamos en cuenta que esta versión española de la teoría de la conspiración fue muy influyente, pues, además de ser parte del discurso nacionalizador y de las formas de identidad nacional que impulsó un sector de la derecha -el más reaccionario-, el conjunto de la derecha tuvo una identidad propia con esquemas de interpretación cargados de símbolos, mitos e imágenes y "un repertorio de significados sobre las causalidades y los acontecimientos del mundo" del que formaba parte la lucha del Bien contra el Mal como motor de la historia (González, 2000: I8-I9).

Una de las aportaciones españolas más relevantes a la teoría de la conspiración judeo-masónica es la realizada por Vicente de la Fuente en los tres volúmenes titulados Historia de las sociedades secretas antiguas y modernas en España y especialmente de la Franc-masonería (1870). Es en el capítulo primero, "Sociedades secretas anteriores a la Francmasonería en España", donde el autor afirma que el origen de la masonería hay que buscarlo en el judaísmo y justifica las persecuciones antisemitas de la Edad Media, precisamente en un 
tiempo en que las matanzas de judíos volvían a estar de actualidad en Rusia. Planteamientos muy parecidos encontramos en las obras de Mariano Tirado y Rojas, Nicolás Serra y Caussa y, en menor medida, con el énfasis puesto en el discurso antimasónico, en textos firmados por Félix Sardá y Salvany, Manuel Polo y Peyrolón y Teodoro Creus y Corominas (Rodríguez, 2007: 727).

Hasta comienzos del siglo xx, el "enemigo" estuvo representado por la masonería y el judaísmo, aunque la primera tuviera escasa influencia en España y el judaísmo no existiera. Dado que el enemigo y los daños causados por este formaban parte de una conspiración secreta, esta resultaría muy difícil de investigar, y de explicar. Este discurso tiene la ventaja de que permite contar pequeñas y grandes mentiras sin que sus propagadores se sientan obligados a presentar sus narraciones con cierta lógica. Cualquier manipulación de hechos históricos o falsificación de documentos, por inverosímil o absurda que parezca, adquiere, para el creyente, categoría de hecho real, al menos verosímil, y, por si acaso, se avisa al público al que va dirigido esta propaganda de que todo aquello que no es posible verificar debe ser creído porque las fuerzas secretas son tan peligrosas como imprevisible su actuación.

Estas ideas se mantuvieron vivas en las filas del tradicionalismo, la derecha radical y el catolicismo político hasta mucho tiempo después. De hecho, va a ser en los años de la Segunda República, la Guerra Civil y el primer franquismo cuando adquieran mayor virulencia, para impulsar y justificar la sublevación militar, la guerra, la represión y la aniquilación del enemigo. A lo largo del periodo comprendido entre abril de I93 I y julio de I936, los portavoces de las derechas que rechazaban el sistema democrático repitieron que la proclamación de la República respondía a una conspiración dirigida desde el exterior y con creciente fuerza en el interior del país (Álvarez, 2002: 30I350; Domínguez, 2009: 74-80). Lo cierto es que en el transcurso de los años inmediatamente anteriores y durante el periodo republicano, la masonería experimentó un notable desarrollo en España, y, tal y como sucediera en Italia y Francia, evolucionó hacia un compromiso político contrario a la derecha católica (Gómez, I998: 223 y ss.). En cuanto al comunismo, era una fuerza de nueva creación, con escasa presencia en el Parlamento, y muy minoritaria respecto al anarquismo y el socialismo. Pero los propagadores de la teoría de la conspiración antiespañola preferían situar como protagonista principal al comunismo (III Internacional, dependiente del PCUS de Stalin), y hablaban menos del socialismo (II Internacional), creyendo que, estableciendo conexiones con la revolución soviética y las "órdenes venidas de Moscú", su propaganda resultaba más eficaz, o sencillamente metían en un mismo saco 
a anarquismo, socialismo y comunismo, en tanto que herramientas de una cabeza rectora superior.

Lo importante era convencer al mayor número posible de personas y, sobre todo, a empresarios y militares, de que la legislación del primer bienio republicano y su continuación por los gobiernos de febrero a julio de 1936 respondía a órdenes del exterior, y para que todo pareciera muy misterioso y, más peligroso, se utilizaba el antisemitismo, el cual formaba parte del universo mental del tradicionalismo, la derecha católica y el fascismo: la conspiración estaría dirigida por el gobierno secreto judío o por la masonería bajo control judío. Dado que era imposible demostrar la existencia del judaísmo como poder en España, y de que el número de españoles de religión o cultura judía era muy bajo (a diferencia de Alemania o Francia), y que no tenían puestos de responsabilidad política ni poseían grandes fortunas, era preciso insistir en que el enemigo actuaba desde el exterior, un Israel o Gran Israel oculto (Álvarez, 2002: 30I-308 y ss.; Rodríguez, 2003a: 4I2-4I3; 2003b). Así pues, se decía: que los protagonistas visibles de la conspiración eran socialistas y comunistas, cuyos dirigentes y militantes tenían presencia en la vida política, mediante partidos, sindicatos y otro tipo de organizaciones; que estos participaron en la Revolución de Octubre de I934; que la dirección parecía estar a cargo de la masonería, organización que había crecido (era sabido que numerosos diputados eran miembros de logias masónicas, y la prensa derechista exageraba esa realidad todo lo posible); y se ponía el énfasis en apuntar que detrás de la masonería estaba la mano del judaísmo. Las editoriales especializadas en la teoría de la conspiración, entre estas Ediciones Antisectarias (Domínguez, 2009: 262-290), y el conjunto de la prensa derechista callaban sobre tres circunstancias: que no existía vínculo alguno entre las logias masónicas y el PCE, que tampoco lo había entre las logias y las sinagogas abiertas en España y que en la URSS los masones habían sido objeto de persecución.

Si durante la etapa republicana este discurso fue utilizado para sembrar el miedo entre los grupos conservadores, deteriorar la imagen de la República entre las clases medias urbanas y los pequeños y medianos propietarios agrarios, para sumar apoyos, primero para que la derecha ganara las elecciones, $y$, a continuación, para un golpe de Estado que liquidara la experiencia republicana, en el transcurso de la Guerra Civil fue utilizado para legitimar la conspiración militar de marzo-julio y la sublevación del I7-I9 de julio de I936, dando a entender que a estos verdaderos conspiradores no les correspondía ninguna responsabilidad en el inicio de la contienda civil. También debía servir para justificar la guerra de tres años de duración y la represión desatada sobre los 
derrotados durante la guerra y la posguerra. De esta forma, la derecha antidemocrática, que había promovido y ejecutado el golpe de Estado, reconstruía la Historia: lo que había sido un golpe contra la legalidad republicana pasaba a ser un movimiento en previsión y respuesta a un proyecto insurreccional, dirigido desde el extranjero y protagonizado por el enemigo interior, que estaría a punto de materializarse. Y la conjura judeo-masónico-comunista se convertía en doctrina oficial para explicar los orígenes de la Guerra Civil, transformada en Cruzada, en guerra de liberación.

En el contexto de la guerra, esta operación de propaganda resultó muy rentable, de cara a las clases medias del interior y los gobiernos y opinión pública en Gran Bretaña, Estados Unidos y otros países. Además, una parte de los nuevos materiales utilizados con fines de propaganda tenían una base real: la revolución social y política que acontece en una parte de la zona republicana, la presencia e influencia creciente del PCE en el Gobierno, la venta de material de guerra a la República por la URSS, y la creación, por la Internacional Comunista, de las Brigadas Internacionales. La propaganda franquista decía que desde Moscú se había trazado el plan para una revolución comunista en España, y que solo se había evitado por el Alzamiento de julio. Por lo dicho, no carecía de lógica que el conjunto de la derecha creyera que todo o parte de esa propaganda era verdad.

El anticomunismo sería, para siempre, el ingrediente fundamental de la contrapropaganda franquista. Siendo así, ahora ganó terreno el antisemitismo. De entre los militares implicados en el golpe de julio del 36, solo el general Mola había destacado como especialista en obras sobre la conjura antiespañola y abrazado la idea de que el judaísmo formaba parte de esta. Pero esta circunstancia cambió por dos motivos. El primero, la radicalización ideológica, previa y acentuada durante la contienda, y la larga duración de esta otorgaron mayor importancia a la propaganda y a la contrapropaganda, dentro y fuera de España. El segundo, el antisemitismo era pieza fundamental del trabajo de la sección exterior del Partido Nazi, y España no fue una excepción, y a esto cabe sumar la labor, durante y después de la Guerra Civil, de personal de la Gestapo y el SD en virtud de varios acuerdos hispano-alemanes de colaboración en materia policial.

Finalmente, en la posguerra, y aún después, la conjura antiespañola se convirtió en doctrina oficial para explicar el porqué de la Cruzada, y también el conjunto de la historia de España de los dos últimos siglos. Asimismo, este tipo de contrapropaganda se iba a aplicar a una de las cuestiones que más interesó al dictador y a sus colaboradores. Se trataba de hacer ver a las bases so- 
ciales y políticas del régimen que el enemigo, derrotado militarmente, seguía siendo peligroso. Y que, para no ser sometidos por la anti-España era preciso cerrar filas en torno a Franco y actuar sin contemplaciones contra quienes se atrevían a insinuar la conveniencia de sustituirle por un rey o de proceder a una apertura política. En definitiva, la teoría de la conspiración establece un enemigo común que actúa como factor de cohesión (Touati-Pavaux, i992: 509; citado por Domínguez, 2009: 449-451), en el caso español durante un largo periodo que incluye la dictadura de Franco; se rentabiliza la utilidad de la conspiración como elemento movilizador contra diversos enemigos, también cohesionados ("los rojos"), y se consigue que tengan menos visibilidad los conflictos internos, tanto los ideológicos como los referidos a la competencia por el poder político.

La teoría de la conspiración fue trasladada de la contrapropaganda a leyes destinadas a perseguir al adversario. Destacan cuatro leyes: la Ley de Responsabilidades Políticas (I939), la Ley para la Represión de la Masonería y el Comunismo (I940), la Ley para la Seguridad del Estado (I94I) y la Ley de Policía de 8 de marzo de I94I, para adecuar la policía a las necesidades de "los estados totalitarios".

\section{La teoría de la conspiración en el organigrama de la policía política franquista}

Aunque en ninguna de esas leyes se cita al judaísmo, los medios de comunicación franquista aumentaron la dosis antisemita durante el periodo I937I943 y varios dirigentes, incluido Franco, incorporaron el antisemitismo a sus discursos. Además, se adoptaron medidas para poner en marcha la persecución de los judíos presentes en territorio español. Y en este cometido la policía política tuvo un papel crucial.

Al comienzo de la Guerra Civil, los dos bandos enfrentados depuraron los cuerpos de funcionarios. En octubre de 1936, una orden circular reguló en la zona franquista la aportación voluntaria de personal civil a las comisarías de policía. Los civiles derechistas y fascistas que habían realizado esa labor desde el comienzo de la guerra podían aspirar al nombramiento de Agente Auxiliar Honorario de la Autoridad y Voluntario en el Cuerpo de Investigación y Vigilancia, la policía secreta (anterior a la guerra) que desempeñaba misiones preventivas en lucha antiterrorista. Desde entonces, hubo sucesivas reformas en la Policía. Tras las primeras medidas adoptadas por la Junta de Defensa Nacional, en octubre del 36, la Junta Técnica asumió las competencias en materia 
policial y creó la Jefatura Superior de Policía, con la misión de cohesionar todos los servicios policiales. Un año después, pasó a denominarse Jefatura de Seguridad Interior, Orden Público e Inspección de Fronteras. Para entonces, la Policía tiene una mayor especialización política, pues existía un Negociado de Masonería, adscrito a la Secretaría General de Masonería. Es la primera vez que se incluye entre las misiones de la policía secreta española la de investigar las logias masónicas. No la tuvo con motivo de la reestructuración de la DGS llevada a cabo en I9ı2, durante la monarquía liberal, cuando una de las brigadas dependientes del Inspector General de Madrid se especializó en anarquismo y socialismo (Caamaño, I999: 200-20I). Y tampoco en noviembre de I930, durante la dictadura del general Dámaso Berenguer, cuando el general Mola, director general de Seguridad, aprobó un nuevo reglamento de la policía gubernativa, que mantuvo dos cuerpos, el de Seguridad y el de Vigilancia, este último con misiones preventivas y funciones "fundamentalmente reservadas, secretas", entre estas elaborar un "Registro de anarquistas, sindicalistas, comunistas, etc".

Cuando en enero de I938, Franco formó su primer gobierno y desapareció la Junta Técnica, apareció un Ministerio de Orden Público, al que quedaron adscritos los servicios de seguridad. En agosto, la jefatura de Seguridad Interior pasó a denominarse del Servicio Nacional de Seguridad. Prueba de la influencia nazi en España es que este Servicio adoptó una estructura organizativa en la que se introducen novedades que nos interesan, pues incorpora un departamento de Masonería y otro de Judaísmo, la primera vez que un organismo policial hacía constar que "el judaísmo" (lo que esto fuera) era objeto de investigación, ambos integrados en la cuarta Sección, Antimarxismo; esa estructura estaba integrada por ocho Secciones y Servicios Activos, entre estos la Brigada Político Social (Caamaño, 2000: 20I-20I). Hubo otras reorganizaciones, a partir de la fusión de los ministerios de Interior y Orden Público en el de la Gobernación, en diciembre de I938.

\section{La doble figura de miembro de la policía política y propagandista de la teoría de la conspiración. Principales figuras}

Nos centramos en dos policías, Julián Mauricio Carlavilla del Barrio y Eduardo Comín Colomer, pues ambos realizan una labor destacada en la policía política franquista, directamente relacionada con la teoría de la conspiración citada. Se trata de los policías-ideólogos que tienen la obra escrita más extensa e influyente en esta materia. No fueron los únicos policías dedicados a estos 
quehaceres, y tampoco fueron una excepción, pero fueron los más activos, exitosos y premiados por este cometido.

\subsection{Carlavilla}

Cuando se proclamó la República, Carlavilla era agente de segunda clase de la División de Investigación Social, la policía política, tras haber pasado por el cuerpo de Vigilancia. El gobierno provisional de la Segunda República suprimió esa División, cambió el nombre del cuerpo de Vigilancia, por el de Investigación y Vigilancia, expulsó a una serie de agentes y trasladó de destino a otros, entre estos Carlavilla, quien en agosto solicitó una segunda baja por dolencia cardiaca. Se dedicó entonces a labores de agitación política al servicio de la extrema derecha. La principal fue la escritura, durante la primavera-verano, y publicación en el otoño de I93I del libro El comunismo en España, que firmó con el seudónimo de Mauricio Karl. En la cubierta del libro, debajo del título, y de símbolos comunistas y anarquistas, leemos: "Mauricio Karl (del Servicio Secreto Internacional)" y "5 años en el Partido, su organización y sus misterios". Además, un "prologuista" presenta a Mauricio Karl como un "alemán y turista profesional", aunque, por sus conocimientos sobre las actividades anarquistas y comunistas en España, merecería, se dice, "ser español por adopción” (Karl, I93I: 5 y 7). A continuación, en "Del autor al lector”, Karl se presenta como extranjero, como miembro de una "entidad internacional" dedicada a desentrañar "el porqué de las cosas, de las pasiones, de sus hombres, de sus ideas y, singularmente, de la política social de sus Gobiernos", y bajo cuyo mandato acabaría de terminar su última misión, que le habría conducido a España: "Vine a España y cumplí laboriosamente la misión secreta que se me había encomendado” (Karl, I93I: Io). Lo que el autor dice haber descubierto son los planes del comunismo español para "la destrucción del actual Estado burgués" en virtud de la libertad de movimiento concedida a los revolucionarios por "las leyes democráticas que surgen del Gobierno republicano" (Karl, I93I: I2). Carlavilla escribe sobre el desarrollo del comunismo y el anarquismo en España. Lo hace relatando sucesos reales e inventados. El libro no contiene críticas directas a la República ni a los políticos que la encarnan, que no tendrían responsabilidad en la creación y crecimiento de los citados movimientos políticos, excepto el de no combatir a los revolucionarios haciendo uso de medidas que el autor considera imprescindibles, pero que no se especifican, crítica que Carlavilla extiende a los anteriores gobiernos de la extinta monarquía. 
Por lo tanto, en esta primera obra de Carlavilla el propósito parece estar enunciado con sutilidad: existe una revolución en marcha, la Monarquía no fue un freno para su expansión, ni siquiera la etapa de gobierno dictatorial de Primo de Rivera, y, en consecuencia, el régimen republicano lo único que hará será acelerar el triunfo del comunismo. Pero los políticos republicanos ni siquiera son citados, ninguno de ellos, como parte del entramado revolucionario. Tampoco se cita a la masonería. Eso sí, el texto va dirigido al público derechista que siempre ha visto en una república la consagración de las ideas que supuestamente amenazarían su forma de vida, también a quienes, por lo menos, desconfían o no se sienten identificados con un régimen republicano como alternativa para la resolución de los problemas nacionales. Ese público estaba siendo convocado desde distintos medios de la derecha para apoyar un movimiento que suprimiera la recién nacida República, y el libro de Carlavilla debe ser situado en ese contexto, siendo su función la de ayudar a crear un estado de opinión.

En el otoño de 1933, Carlavilla regresó al Cuerpo de Investigación y Vigilancia. También retomó su labor de propaganda con el seudónimo de Mauricio Karl. Lo hizo publicando en I934 El enemigo. Marxismo. Anarquismo. Masonería, título reeditado los dos años siguientes. El enfoque es distinto al de El comunismo. No porque en las páginas introductorias Carlavilla se presente en esta ocasión como español, como un guerrillero en lucha contra los enemigos de España. Lo esencial es su ataque a la masonería, "organización minoritaria en relación a las fuerzas que inspira, dirige y controla" (Karl, I935: I5), y a los judíos: "Nosotros le concedemos a los judíos tanta importancia que les asignamos la alta y suprema dirección de todos los internacionalismos: Masonería, anarquismo, marxismo... y las finanzas" (Karl, I935: 24). Después siguen páginas dedicadas a la "interpretación masónica de la Historia de España", sin citar como fuente a los tradicionalistas españoles del xIX ni a autores coetáneos, como el presbítero Juan Tusquets.

Mientras aparecen sucesivas ediciones de sus dos primeros títulos, Mauricio Karl ultima la segunda parte de El enemigo. Aparece en I935 con el título de Asesinos de España. Marxismo. Anarquismo. Masonería. La obra está dedicada "Al Ejército de España, vencedor de la revolución de octubre. A los que supieron morir y matar". Sus páginas aportan pocas novedades a lo ya visto, aunque en esta ocasión los judíos apenas se hacen presentes. Lo que pretende el autor es aprovechar el tirón de ventas de los textos anteriores, en lo que posiblemente influyen los hechos revolucionarios de octubre de I934, y seguir colaborando en la creación de un estado de opinión favorable a un golpe de 
Estado. Se explaya sobre el siglo xix español, sin citar a sus fuentes, y después se ocupa de hechos recientes desde su particular perspectiva, hasta desembocar en la revolución de Asturias, y también de algunos políticos concretos. La parte final está dedicada a avisar de una supuesta e inminente revolución en España, dirigida por la masonería, y cita como protagonistas "masones" a una serie de políticos, algunos de los cuales eran miembros de logias y otros no, incluyendo a un nacionalista catalán: Companys, Azaña, Bello, Largo Caballero, Barcia, Martínez Barrio, Pestaña, Seguí, Ascaso y otros.

En septiembre, el mismo mes en que apareció su tercer libro, Carlavilla solicitó tres meses de licencia sin sueldo, según dijo para atender a su salud y resolver asuntos particulares. Esos asuntos debían de ser de índole política. Pues dos meses antes, a partir de oficio de la asesoría jurídica de la DGS, se le había abierto expediente gubernativo para averiguar si era el autor de los libros firmados con el seudónimo de Mauricio Karl, en los cuales la superioridad había apreciado elementos delictivos. Le fue instruido expediente disciplinario por faltas graves ${ }^{2}$ y en octubre fue expulsado del Cuerpo por no responder a preguntas sobre si Mauricio Karl era él y por mezclarse en asuntos políticos siendo funcionario del Estado3. Durante ese otoño, Carlavilla participó en la planificación de un atentado contra el presidente de la República, junto a varios civiles, expolicías y agentes en activo ${ }^{4}$. Sobre la implicación de Carlavilla en los hechos disponemos de dos documentos. El primero deja constancia de que el Juzgado de Instrucción n. ${ }^{\circ}$ 6, encargado de la investigación, dictó orden de busca y captura de Carlavilla "por tentativa de asesinato y depósito ilícito de armas de fuego"s. El segundo es una declaración del propio Carlavilla, en la que asegura haber actuado por orden de la Unión Militar Española ${ }^{6}$.

A la espera de un golpe militar, Carlavilla huyó a Portugal, de donde regresó tras el comienzo de la Guerra Civil, para servir al nuevo Estado franquista. En el otoño de I936, se integró en el equipo de asesores de Franco coordinado

\footnotetext{
${ }^{2}$ Archivo General de la Policía (AGP), Ministerio del Interior, Archivo Bajas (AB), expediente I.376, doc. I40. También hay información al respecto en la declaración prestada en I940, documento 272.

3 Ibídem, documento I29.

${ }^{4}$ Ibídem, documento 272 y expediente personal del policía Juan Antonio Escobar Raggio, Dirección General de la Policía, AB, expediente n. ${ }^{\circ} 4542$.

${ }_{5}^{5}$ AGP, AB, expediente I.376. Dirección General de Seguridad (DGS). Sección de Personal, ıo de noviembre de I952, sin número de documento.

${ }^{6}$ Declaración prestada en I940 cuando, tras solicitar el reingreso en el servicio, fue abierta una investigación para dilucidar los antecedentes, ideología y actuación de Carlavilla "con relación al Glorioso Movimiento Nacional". AGP, AB, expediente I.376, doc. 272.
} 
por el hermano de este, Nicolás. Sin embargo, a finales de año regresó a Portugal y realizó funciones policiales al servicio de la embajada, a partir de un compromiso verbal, al tiempo que se dedicaba a actividades ilegales, sobre todo al contrabando de divisas. Al ser expulsado por las autoridades portuguesas, regresó a España y, en mayo de I940, solicitó y obtuvo el reingreso en el cuerpo de Investigación y Vigilancia. Durante los años siguientes encadenó varias llamadas de atención de sus mandos, la dirección de una Brigada Especial, secreta, licencias por enfermedad, excedencias y la reincorporación al cuerpo. En I942 fundó la editorial Nos, especializada en la teoría de la conspiración, donde aparecieron textos de otros autores y del propietario, entre estos Sodomitas (I956), que incorpora el tema de la homosexualidad (ya tratado por otro policía-ideólogo, Vicente Reguengo), Satanismo (I957), y Anti-España 1959 (I959), donde lo principal es la vinculación de la figura de Juan de Borbón con la masonería.

Posiblemente, la editorial ingresaba poco dinero, de hecho, Carlavilla llegó a vivir con su familia en una dependencia policial. Por este motivo, y, aunque parezca una contradicción, por haberse descubierto que había participado en un negocio de compra-venta de joyas, solicitó el reingreso en la policía. Gracias a sus contactos y a la valoración de su obra escrita, fue readmitido. Incluso, en I947 fue nombrado inspector de primera clase del Cuerpo General de Policía y en enero de I948 ingresó en la Escuela General de Policía para realizar el curso de capacitación para la escala de mando. En marzo de I957 ascendió a comisario principal y en febrero de 1958 se jubiló como policía. Para entonces, el interés por su obra había sido decreciente y muy poco más publicaría. Carlavilla falleció en junio de I982.

\subsection{Comín Colomer}

Por lo que se refiere a Comín Colomer, ejerció labores de periodista para varias publicaciones derechistas en Zaragoza, y también de representante comercial, se vinculó a la CEDA, suspendió las oposiciones a la Policía y, cuando tuvo lugar la sublevación militar de julio de I936, se unió a esta. Ese mes realizó tareas de vigilancia y represión en la capital aragonesa y sus alrededores, sobre todo contra elementos anarquistas7, y se incorporó al cuerpo como

\footnotetext{
7 Declaración jurada firmada por Comín el 2-9-I94I, Archivo de la DGS, Inspección General de Personal, Bajas, n. ${ }^{\circ} 7958$.
} 
auxiliar, inscrito en el Centro de Investigación y Vigilancia. En octubre, Comín tenía ya el nombramiento de Agente Auxiliar Honorario de la Autoridad y Voluntario en el Cuerpo de Investigación y Vigilancia. Recibió destino en la Jefatura Superior de Policía en Valladolid, donde trabajó en los Archivos Policiales. En octubre de I937 fue la persona elegida para coordinar el negociado de Masonería adscrito a la Secretaría General de Masonería, dependiente de la jefatura del Servicio Nacional de Seguridad. Durante este tiempo realizó el cursillo para Agente Auxiliar Interino y, en agosto de I938, unos días después de la firma del acuerdo hispano-alemán de colaboración policial, fue escogido para dirigir dos departamentos, Masonería y Judaísmo, de los tres (el otro era Publicaciones) que integraban la sección Antimarxismo del citado Servicio. Además, se encargó de redactar los textos del Boletín de Información Antimarxista editado por la DGS, aparecidos entre el 20 de octubre de 1938 y el 3I de enero de I939, los cuales se remitían a los cuerpos de Investigación y Vigilancia y a los distintos ministerios.

En enero de I939, a tres meses del final de la Guerra, Comín fue requerido para prestar servicio de secretario particular del jefe de la Delegación del Estado para la Recuperación de Documentos, organismo dedicado a la búsqueda y catalogación de los emanados de las organizaciones consideradas desafectas al régimen, los cuales iban a ser utilizados para la persecución política. Comín organizó sus archivos en las plazas de Barcelona, durante febrero y marzo, y Valencia, durante abril y mayo, a partir de la confiscación de la documentación de sindicatos, partidos, ateneos, sinagogas, logias masónicas y domicilios particulares de quienes figuraban en las listas elaboradas por los comisarios de Investigación y Vigilancia antes de la entrada en esas ciudades de las fuerzas franquistas. Tras ser examinada, la documentación se enviaba al archivo que comenzaba a formarse en Salamanca para una segunda fase de la persecución a los desafectos. En uno de los oficios remitidos por Comín desde Barcelona al delegado, con fecha de 25-3-1939, queda constancia de los registros y confiscación de documentos y diversos objetos en las logias masónicas y la sinagoga:

Otro pequeño triunfo ha sido el obtener lo que la Brigada Social había recogido en el templo judío. Alguna documentación y muchos libros en hebreo, pero hemos marcado un jalón. Me consultaron telefónicamente desde la Jefatura lo que había de hacerse y yo les dije que darnos todo para el mejor cumplimiento de lo que hay dispuesto. Por tanto guardamos todo lo judío para Servicios Especiales ${ }^{8}$.

\footnotetext{
${ }^{8}$ Archivo General de la Guerra Civil Española, DNSD, Exp. Secretaría, exp. 42.
} 
A mediados de mayo de I939, Comín se reintegró al Servicio Nacional de Seguridad en Valladolid. Fue designado representante en la Sección Antimarxista en la Sección Central, surgida de una reorganización de los servicios. Con José Finat al frente de la DGS, desde septiembre de I939 (cargo que compaginaba con el de delegado nacional del Servicio de Información e Investigación de FET y de las JONS), y de Ramón Serrano Suñer del Ministerio de la Gobernación y, a continuación, del de Exteriores, aumentó la colaboración con el Tercer Reich; Heinrich Himmler, jefe de las SS y de la RSHA, visitó España en I940, y Heinrich Müller, jefe de la Gestapo, en I942. Pues bien, al margen del organigrama policial descrito, entre I940 y, al menos, I94I, actuaron una o varias secciones de policía cuya existencia, no solo su trabajo, era secreta. Carlavilla fue parte de esta operación: cuando Finat organizó una Brigada Especial fue él la persona puesta al mando 9 . Es posible que entre las misiones asignadas figurara la de identificar y controlar a los judíos residentes en España, actividad que dio comienzo en I939.

Además, la Ley de Policía de 8 de marzo de I94I restructuró el cuerpo, dotando a los servicios de Vigilancia y Seguridad de una nueva organización interna, muy centralizada y politizada; el cuerpo de Investigación y Vigilancia pasó a denominarse Cuerpo General de Policía. Su función política, acorde, se dice, a "los estados totalitarios", quedó reflejada en el preámbulo de la ley. La existencia de una policía política había pasado a ser un requisito para el funcionamiento del Estado próximo al totalitarismo por el que, bajo la influencia del Partido único, FET y de las JONS, y del nazismo, Franco se inclinaba entonces. Un mes después, Comín se reincorporó a la sección Antimarxismo del Servicio Nacional de Seguridad. Además del trabajo ordinario de la oficina, se hizo cargo de la confección del Boletín de Información Antimarxista, cuya reaparición había sido acordada y que tuvo periodicidad mensual o bimensual. A finales de mayo, fue designado redactor único de los contenidos principales, con títulos como "La Francmasonería. Ritos antiguos y modernos. Organización universal" y "La Internacional Comunista o Comintern" (Fernández, I989). En sus páginas se repiten las supuestas conexiones entre masonería, comunismo y judaísmo, en ocasiones como resultado de un plan diabólico. Estos textos, así como las secciones dedicadas a disposiciones legales de carácter antimasónico y anticomunista vigentes en otros países, a las medidas tomadas en estos para salvaguardar el "orden social", y a documen-

9 Información recogida en el expediente de Juan Antonio Escobar Raggio, Dirección General de la Policía, AB, exp. 4542. 
tación auténtica, pero manipulada para su publicación tras haber sido confiscada, ayudaban a conformar la voluntad de los funcionarios en tanto que intérpretes de una misma "cruzada". Debían tener claro que la persecución de masones, comunistas y anarquistas era una causa noble. Solo así los policías cumplirían eficazmente con el trabajo asignado, la detención y obtención de información de las personas señaladas, sabiendo que una parte serían ejecutadas. El boletín se publicó hasta octubre de i945. A finales de 1946 comenzaría a editarse una publicación semejante, aunque más extensa y de más larga vida, el Boletín Informativo, de circulación reservada a los funcionarios del Cuerpo General de Policía, y que acabaría ejerciendo de órgano interno de la División de Investigación Social de la DGS. El índice se componía de los siguientes apartados: Actividad Internacional, Extranjero y Actividades contra España. Este boletín se publicó hasta octubre de I977.

Otra manifestación de la colaboración con la Alemania nazi en materia policial fue la orden cursada por el director de la DGS el 5 de mayo de I94I, para la vigilancia de los judíos que se encontraban en España, muy especialmente a los de origen español, catalogados como enemigos, y proceder a informes individuales destinados a la creación de un fichero. Una parte de la información necesaria para este fichero tuvo que proceder del trabajo hecho por Comín, y posiblemente de Carlavilla. Esa orden incluye la petición a los gobiernos civiles de informes sobre "las actividades de carácter judaico", y de "informes individuales de los israelitas, nacionales y extranjeros, avecindados en esa provincia” (Israel Garzón, I997-I998 $8^{\text {Io }}$ ). No sabemos cuándo se interrumpió ese fichero, pero hay constancia de su funcionamiento en junio de I944, según documento de la Comisaría General Político-Social de Madrid que hace referencia al "archivo judaico de la sección". A partir de ese archivo, la embajada alemana cursó peticiones de refugiados y una parte fueron atendidas; las entregas se pueden rastrear hasta el verano de ese mismo año.

La carrera de Comín en la Policía fue muy exitosa, por su eficacia en la doble función de funcionario de la policía política y propagandista de la teoría de la conspiración. En I94I llegó su primer libro. Autorizado por el mando, fue coautor, con Nicolás Rodinevitch (exiliado ruso al servicio de la DGS), de La Internacional Comunista o Komintern y sus organizaciones auxiliares. Fue ascendiendo y a mediados de I943 pasó a la Comisaría General Político-Social de la DGS, donde dirigió el Negociado Político-Social. Personaje autodidacta, y con mucho ego, en I945 se ofreció al director de la DGS para impartir una

10 La documentación en Archivo Histórico Nacional, signatura 36.I45. 
asignatura de nueva creación en la Escuela General de Policía, a la que denominó Técnica de Investigación Social, y recibió el visto bueno en calidad de conferenciante; la asignatura se consolidó y pasó a llamarse Cuestión Político-Social, y Comín fue requerido para dar también clases de grado superior, para inspectores, de perfeccionamiento, para agentes de segunda clase, y de grado profesional, para agentes-alumnos. En el manual que escribió recomendaba a los alumnos de Investigación Social proceder a información y represión con carácter preventivo, evitando así que "la conspiración trascienda al público", y dejaba dicho que algunos métodos de investigación solo serían explicados en las clases, pues "no todo aquello que se sabe, se comprende o se deduce, puede y debe darse a la letra impresa"II.

En I947 dio otro paso más para servir a los ideales del régimen de Franco. Comín y otros tres policías, entre los que figuraba Juan Antonio Escobar, comisario y profesor en la Escuela General de Policía, en calidad de director, pusieron en marcha la revista Policía Municipal, que mezclaba contenidos técnicos, legislativos e ideológicos. Para continuar afianzando su posición, en I949 Comín obtuvo el título de periodista por la Escuela Oficial de Periodismo, aunque no lo habría necesitado para sus labores de propaganda. Escribió artículos en los semanarios El Español y Juventud, en Gaceta de la Prensa Española, Revista Internacional, Ateneo y Revista de Estudios Históricos de la Guardia Civil, además de en publicaciones de ámbito policial. A esto añadió una intensa labor de conferenciante en centros oficiales y no oficiales. Y no paró de multiplicar sus aportaciones a la lucha contra la subversión.

Casado y sin hijos, Comín escribió varios libros, numerosos folletos y decenas de artículos, casi siempre como autor único, a veces junto a otros policías propagandistas. Para sus contenidos, Comín se inspiró en libros anteriores sobre la conspiración antiespañola, que casi nunca cita. Si uno de los libros de Tirado y Rojas se titula La masonería en España. Ensayo histórico (I892-1893), Teodoro Creus y Corominas fue autor de La Masonería y su intervención en los principales sucesos políticos de los tres últimos siglos (1899), y Manuel Polo y Peyrolón de Intervención de la masonería en los desastres de España (también de I899, tras el 98), uno de los libros de Comín tiene como título La masonería en España (Apuntes para una interpretación masónica de la historia patria), de I944. En sus diecinueve capítulos, la historia es una lucha permanente entre España y la anti- España, o el Bien y el Mal, y el lector debe

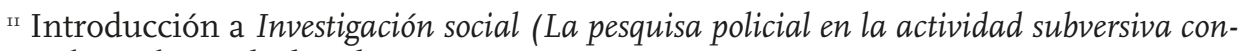
tra el Estado, Madrid, Policía, I947.
} 
tomar nota de ello, sin olvidar que él mismo ha tenido y tiene la oportunidad de ser protagonista de la historia que se le muestra en el último capítulo; y, por supuesto, la obligación de tomar partido. Más adelante, Comín, como Carlavilla, que le hizo el prólogo, retomó otro de los temas preferidos de los verdaderos conspiradores, el de los crímenes políticos, siempre debidos a los secretos designios de la masonería o a la acción conjunta de la masonería y el judaísmo. Según leemos en Un siglo de atentados políticos en España (de I95I, el año que ascendió a agente de primera clase), a las manos de la masonería se habrían debido, entre otras, las muertes de Juan Prim (sería el caso de un masón monárquico asesinado por masones republicanos), Antonio Cánovas del Castillo (otro masón asesinado por masones, "era un miembro predilecto de las logias", pues, se dice, la restauración de la monarquía borbónica había contado con el beneplácito de "la Masonería universal", especialmente de las logias británicas), José Canalejas, Miguel Primo de Rivera y, buscando acontecimientos próximos a sus lectores, José Calvo Sotelo, cuya suerte se habría decidido en una reunión masónica en Francia (Comín, I951: 287 y ss.); para que nada falte, una edición ampliada de ese libro incluirá como crimen masónico la muerte del general José Sanjurjo.

En I954, Comín ascendió a inspector de primera clase. De esta década son varios de sus libros principales, comenzando por Lo que España debe a la masonería (1952), que incluye abundantes referencias a la invasión de España por las tropas napoleónicas en I808, la revolución de I868, la Primera República, la Segunda República y la Guerra Civil, y, por supuesto, a la pérdida de los restos del imperio en el 98, con epígrafes como "La Masonería, ejemplo y causa de la pérdida de Cuba". Respecto al capítulo dedicado a la Segunda República, algunos de los epígrafes son los siguientes: "Instalación oficial de la República masónica”; "Alcalá Zamora y Miguel Maura, juguetes de la Secta"; "Quema de conventos, o consigna reverdecida"; "Una Constitución de acuerdo con las inspiraciones de las logias"; "La revolución de octubre, obra de la Secta" y "Frente Popular incubado por los talleres". Comín volvió sobre estos temas, para escribir siempre lo mismo, fuese cual fuese el periodo de la historia al que prestaba atención, en Historia secreta de la Segunda República (1954), en dos volúmenes que cubren la cronología I830-I955, y en La República en el exilio (1957). Comín se cuidó de no emitir opiniones sobre la actualidad política española, dando muestras de una prudencia de la que carecía Carlavilla. La masonería seguiría siendo una obsesión, en parte porque, tal vez, se había creído todas las patrañas al respecto elaboradas desde las filas de la derecha tradicional y la derecha radical, y deseaba aportar su granito de 
arena, y en parte porque le reportaba buenos rendimientos a nivel económico: venta de ejemplares y, lo principal, premios en metálico en su nómina de policía y valoraciones muy positivas de sus superiores inmediatos y de políticos con los que se relacionaba. Uno de sus artículos, "Bibliografía de la guerra de liberación”, en la Revista del Instituto de Estudios Políticos, en I952, le valió el Premio de la Dirección General de Información, dotado con ro.০oo pesetas, en calidad de "mejor bibliografía de la Cruzada".

En febrero de 1959, Comín fue designado secretario general técnico de la Comisaría General de Investigación Social, en enero del mismo año ascendió a inspector jefe del Cuerpo General de Policía, y en marzo de i962 a comisario de segunda clase. Además, Comín trabajó en programas de radio, de contrapropaganda, entre los que figuran las emisiones en lengua rusa de Radio Nacional de España, preparando borradores de propaganda antimarxista y descripciones de la situación en los países del Telón de Acero, y colaboró en la revista Policía, publicación del Cuerpo General de Policía, que pasaría a dirigir en I962. De lo expuesto se deduce que dentro del aparato policial franquista existió una estructura ideológica conformada por un conjunto de publicaciones, que ese entramado fue determinante para justificar la represión de la dictadura y que Comín fue una pieza fundamental de este. Fue, además, coleccionista de libros y folletos de autores nacionales y extranjeros vinculados a la extrema derecha y el fascismo y también de libros de contenido "subversivo", hasta formar una gran colección que integra en la actualidad el Fondo Comín Colomer en la Biblioteca Nacional. Vivió menos que Carlavilla, pero su carrera fue más exitosa. En I968 fue nombrado director de la Escuela General de Policía y al año siguiente director del Instituto de Estudios de la Policía, además de ascender a comisario de primera clase. En octubre de I973 pasó a la situación de jubilado y fue distinguido con el título de director honorario de la Escuela General de Policía. Falleció en enero de I975.

\section{Conclusiones}

A partir de los datos presentados, creemos que la figura individual de policía especializado en la persecución política y la doble figura de miembro de las unidades de policía política del franquismo y de propagandista de la teoría de la conspiración judeo-masónica-comunista aportan arquetipos de perpetración de violencia. En tanto que ejecutores de órdenes de investigación, persecución y apresamiento de personas, Carlavilla, Comín y otros policías son per- 
petradores de violencia política, con consecuencias físicas sobre los declarados enemigos: miedo, cárcel, torturas, exilio, en ocasiones la ejecución. En tanto que autores de relatos en los que se falsean los acontecimientos históricos, se denigra el antifranquismo y se justifica tanto la represión en marcha (en las primeras obras) como la realizada durante la guerra y la posguerra (en las obras posteriores) e incluso la que estaba por venir, manteniendo vivo el espíritu de Cruzada, son perpetradores de una violencia verbal y aparentemente no física, pero con consecuencias físicas: causa miedo y genera violencia desde las fuerzas de seguridad, por ejemplo las clases impartidas por Comín en la Escuela General de Policía. Esta doble figura no es específica del franquismo y sería interesante realizar estudios comparativos con otras dictaduras.

La teoría de la conspiración española resultó tan útil como poco original y apenas fue renovada. En cuanto a la versión española que los policías Carlavilla y Comín retoman y alimentan, las intenciones son las mismas que en los autores que les preceden en este cometido. Asimismo, son los mismos los causantes de "los males de España", básicamente masonería y comunismo. Pero apreciamos variaciones en cuanto a las herramientas utilizadas por esas "agencias del Mal" cuando se producen cambios en las coyunturas, la interior y la internacional. Eso sí, van a ser variaciones sobre un mismo tema. El más incisivo fue Carlavilla. Tratar del satanismo era regresar a la Edad Media y a los autores españoles del siglo xix inspirados en sus colegas franceses, pero algunos policías introdujeron el tema de la homosexualidad, Reguengo y principalmente Carlavilla, que, en Sodomitas, que aportaba "un esquema histórico de la sodomía en su función comunista", con un relato que viene a demostrar que la censura nacional católica no era para todos, incluyó capítulos dedicados a Manuel Azaña y Diego Martínez Barrio. Carlavilla también atacó a los monárquicos juanistas, incluido su pretendiente al trono, e, incluso, se atrevió con la Iglesia católica, con motivo de las reformas introducidas por el Concilio Vaticano II y su repercusión en España; es de interés señalar que el libro sobre la Iglesia se editó en Sudamérica.

La figura del policía-ideólogo como perpetrador de violencia es parcialmente esquiva, dado que se han hecho escasas investigaciones sobre esta materia, pero queda demostrada su existencia, y su utilidad, y necesidad, para el franquismo, y para cualquier dictadura, aunque la parte ideológica la pueda realizar un militar $u$ otro profesional especializado en guerra contrasubversiva. No creemos que exista dificultad para identificar otras figuras concretas. Al consultar la documentación sobre los dos policías que considerábamos figuras principales del arquetipo, examinando las obras firmadas por más de 
un autor, y otras colaboraciones, surgen otros nombres, entre estos los de Juan Antonio Escobar Raggio, Vicente Reguengo, Eloy de la Peña y Tomás Cossías. Es posible rastrear datos de ellos en el Archivo General del Ministerio del Interior y, tal vez, en otros archivos; examinando otras publicaciones, como la revista Policía, podremos avanzar más. Añádase que, en el informe realizado por Babiano, Gómez, Míguez y Tébar para la querella argentina contra los crímenes del franquismo, figuran los nombres de varios policías (2018: I40-I49). No obstante, es muy posible que buena parte de la documentación relativa a la Brigada Político Social fuera destruida, la relativa a la guerrilla, partidos clandestinos, juanistas, masonería y otras cuestiones; en I979, el Ministerio del Interior lo habría ordenado así en previsión de que una victoria electoral del PSOE propiciara la salida a la luz de documentación sobre la persecución a izquierdistas ${ }^{\mathrm{I} 2}$.

\section{Bibliografía}

Alcántara Pérez, Pablo. 2020. El águila gris: la policía política durante la dictadura franquista en Asturias y Madrid (1956-1976) (Tesis Doctoral). Universidad Autónoma de Madrid.

Álvarez Chillida, Gonzalo. 2002. El antisemitismo en España. La imagen del judío (18122002). Madrid: Marcial Pons.

Babiano, José; Gómez, Gutmaro; Míguez, Antonio \& Tébar, Javier. 20I8. Verdugos impunes. El franquismo y la violación sistémica de los derechos humanos. Barcelona: Pasado y Presente.

Caamaño Bournacell, José. I999. La Policía a través del tiempo (1908-1958). Madrid: Secretaría de Estado de Seguridad.

Cohn, Norman. I980. Los demonios familiares de Europa. Madrid: Alianza.

Cohn, Norman. I983. El mito de la conspiración judía mundial. Los Protocolos de los sabios de Sión. Madrid: Alianza.

Comín, E. I951. Un siglo de atentados políticos en España. Madrid: Selecciones Gráficas.

De Antón, Julio. 2000. Historia de la policía española. Madrid: Unilibro.

Domínguez Arribas, Javier. 2009. El enemigo judeo-masónico en la propaganda franquista 1936-1945. Madrid: Marcial Pons.

Fernández Fernández, Pedro Víctor. I989. El Boletín de información anti-marxista: un ejemplo de espíritu antimasónica del franquismo. En Ferrer Benimeli, José Antonio (coord.) Masonería, revolución y reacción. Diputación Provincial de Alicante, vol. I, 44I- 460 .

Ferrer Benimeli, José Antonio. I982. El Contubernio Judeo-Masónico-Comunista. Del Satanismo al escándalo de la P-2. Madrid: Istmo.

${ }^{12}$ Entrevista con el policía e historiador Manuel Turrado Vidal en Madrid, el IO-I-2000. 
Gómez Molleda, M. ${ }^{a}$ Dolores. 1998. La Masonería en la crisis española del siglo xx. Madrid: Universitas.

González Cuevas, Pedro Carlos. 2000. Historia de las derechas españolas: de la Ilustración a nuestros días. Madrid: Biblioteca Nueva.

Israel Garzón, Jacobo. I997-I998. El Archivo Judaico del franquismo. Raíces 33.

Karl, Mauricio. I93I. El comunismo en España. Madrid: Imp. Sáez Hermanos.

Karl, Mauricio. I935. El enemigo. Marxismo. Anarquismo. Masonería. Madrid: Ediciones Bergua.

López Garrido, Diego. I987. El aparato policial en España. Barcelona: Ariel.

Poliakov, León. I982. La causalidad diabólica. Ensayo sobre el origen de las persecuciones. Barcelona: Muchnik.

Rodríguez Jiménez, José Luis. s. a. Funcionarios de la policía franquista al servicio de la teoría de la conspiración: El caso de Comín Colomer. En Ferrer Benimeli, José Antonio (coord.). La masonería española en el 2000. Una revisión histórica. Zaragoza: Gobierno de Aragón, vol. II, 92I-935.

Rodríguez Jiménez, José Luis. 2002. La función de la conjura judeo-masónica-comunista en la propaganda franquista. La aportación de la policía política. Lleida: Associació Recerques/Pagès Editors, vol. II, II70-II8I.

Rodríguez Jiménez, José Luis. 2003. Una aproximación al trasfondo ideológico de la represión. Teoría de la conspiración y policía política franquista. En Sobrequés, J.; Molinero, C. \& Sala, M. (eds.) Los campos de concentración y el mundo penitenciario en España durante la guerra civil y el franquismo. Barcelona: Museu d'Història de Catalunya y Editorial Crítica, 4II-420.

Rodríguez Jiménez, José Luis. 2003. El discurso antisemita en el fascismo español. En Tusell Gómez, Javier \& Ferrer Benimeli, José Antonio. Los judios en la Historia de España. Calatayud: Diputación Provincial de Zaragoza, 89-I29.

Rodríguez Jiménez, José Luis. 2004. Las mentiras de un converso y falso masón: La aportación de Joaquín Pérez Madrigal a la teoría de la conspiración antiespañola. En Ferrer Benimeli, José Antonio (coord.) La Masonería en Madrid y en España del siglo XVIII al XXI. Zaragoza: Gobierno de Aragón, vol. II, pp. I303-I322.

Rodríguez Jiménez, José Luis. 2007. Herramientas de trabajo: los contenidos de la conspiración antiespañola. En Ferrer Benimeli, José Antonio (coord.) La masonería española en la época de Sagasta. Zaragoza: Gobierno de Aragón, vol. II, 725-745.

Rodríguez Jiménez, José Luis. 20ıo. Carlavilla, un personaje al servicio de las teorías conspirativas judeo-masónico-comunistas y de la conspiración contra la Segunda República Española. En Ferrer Benimeli, José A. (coord.) La masonería española. Represión y exilios. Zaragoza, Gobierno de Aragón, vol. II, 87I-885.

Touati-Pavaux, Corinne. I992. La séduction de la Conspiration. De la représentation de la réalité à la réalité de la représentation. En Pierre-André Taguieff (dir.) Les Protocoles des sages de Sion. Faux et usages d'un faux. París: Berg International, vol. II, 499-536.

Turrado Vidal, Martín. 2000. La policía en la historia contemporánea de España (17661986). Madrid: Dykinson. 
